\title{
Optimized production and properties of thermostable alkaline protease from Bacillus subtilis SHS-04 grown on groundnut (Arachis hypogaea) meal
}

\author{
Folasade M. Olajuyigbe \\ Department of Biochemistry, School of Sciences, Federal University of Technology, Akure, Nigeria; \\ folajuyi@futa.edu.ng
}

Received 10 July 2013; revised 19 August 2013; accepted 5 September 2013

Copyright (C) 2013 Folasade M. Olajuyigbe. This is an open access article distributed under the Creative Commons Attribution License, which permits unrestricted use, distribution, and reproduction in any medium, provided the original work is properly cited.

\begin{abstract}
Production of alkaline protease from Bacillus subtilis SHS-04 was investigated under different fermentation conditions involving low-cost substrates with the aim of optimizing yield of enzyme. Maximum enzyme production (1616.21 $\mathrm{U} / \mathrm{mL}$ ) was achieved using groundnut meal $(0.75 \%)$ as nitrogen source and $0.5 \%$ glucose as carbon source at $48 \mathrm{~h}$ cultivation period, $\mathrm{pH} 9$, $45^{\circ} \mathrm{C}$ and $200 \mathrm{rpm}$. The yield was $348 \%$ increase over comparable control samples. The alkaline protease had optimum temperature of $60^{\circ} \mathrm{C}$ and remarkably exhibited $80 \%$ relative activity at $70^{\circ} \mathrm{C}$. It was highly thermostable showing $98.7 \%$ residual activity at $60^{\circ} \mathrm{C}$ after 60 minutes of incubation at $\mathrm{pH} 9.0$ and was stable in the presence of organic solvents studied. These properties indicate the viability of the protease for biotechnological and industrial applications. The optimized yield of enzyme achieved in this study establishes groundnut meal as potential low-cost substrate for alkaline protease production by $B$. subtilis SHS- 04 .
\end{abstract}

Keywords: Alkaline Protease; Bacillus subtilis SHS-04; Groundnut (Arachis hypogaea) Meal; Low-Cost Substrate; Thermostable

\section{INTRODUCTION}

Proteases constitute one of the most important groups of global industrial enzymes accounting for about $60 \%$ of the total enzyme sales [1]. Among the different types of proteases, alkaline proteases have wide applications in the detergent, leather and pharmaceutical industries [2]. Bacterial proteases are the most significant, compared with plants, animal and fungal proteases because they are mostly extracellular and easily produced in large amount, but their usefulness is limited by various factors, such as instability at high temperatures, extreme $\mathrm{pH}$, the presence of organic solvents and the need for co-factors [3]. The present known proteases are not sufficient to meet industrial demands hence, there is a continuous search for new proteases with novel characteristics for industrial applications from diverse bacteria isolates.

Enzyme production by any organism is influenced by many factors such as $\mathrm{pH}$, incubation temperature, incubation time, growth rate of culture and medium composition [4]. Currently, the overall cost of enzyme production is high and the growth medium accounts for about $30 \%$ $40 \%$ of the production cost [5]. Reducing the cost of enzyme production by optimization of fermentation medium and process parameters is the major goal of basic research for industrial applications [6]. To this extent, the search for inexpensive carbon and nitrogen sources such as agricultural residues and marine by-products for use in media composition for protease production has been continuous.

Maximum protease synthesis by alkalophilic Bacillus $s p$. I-312 was obtained when the bacterium was grown in a medium containing wheat flour and soybean meal as carbon and nitrogen sources [7]. Bacillus licheniformis RP1 was shown to produce proteases when grown in media containing shrimp wastes powder as a sole carbon and nitrogen source [8]. Mirabilis jalapa tuber powder (MJTP) was used as organic substrate for the growth and production of fibrinolytic serine protease by Bacillus amyloliquefaciens An6 [9].

Groundnut (Arachis hypogaea) is a species in the legume family, Fabaceae, native to South America and cheaply cultivated in African, Asian and Arab countries [10]. Groundnut provides an inexpensive source of high quality dietary protein and oil. Groundnut seed contains 
$25 \%$ to $28 \%$ protein and $46 \%$ to $51 \%$ oil on a dry seed basis and it is a rich source of minerals (phosphorus, calcium, magnesium, and potassium) and vitamins (E, K, and $\mathrm{B}$ group) [11-13]. The proximate analysis and nutriational value of groundnut suggest groundnut meal as potential low-cost substrate in media composition for microbial growth and enzyme production. In this study, effects of low-cost substrates including groundnut meal and process parameters were investigated on protease production and properties of the crude enzyme were determined.

\section{MATERIALS AND METHODS}

\subsection{Materials}

Media components were products of Sigma-Aldrich (St Louis, MO, USA) except groundnut seeds, soybean meal, yam (Dioscorea alata) flour and locust bean meal which were purchased from the local market and processed using standard sieve. Groundnut meal was prepared by sun drying fresh groundnut seeds for two weeks. The dried groundnut seeds were pulverized and stored in glass bottles at room temperature. All other chemicals used were of analytical grade and obtained from Fisher Scientific.

\subsection{Bacterial Strain}

The microorganism used in this study was an alkaliphilic bacterium isolated from the soil of a slaughterhouse. Samples collected were plated onto skim-milk agar plates and were incubated $24 \mathrm{~h}$ at $37^{\circ} \mathrm{C}$. A clear zone of skim-milk hydrolysis gave an indication of protease-producing strains. Individual colonies were purified through repeated streaking on fresh agar plates. Depending upon the zone of clearance, isolate SHS-04 was selected for further experimental studies. This isolate was identified as $B$. subtilis in the Biotechnology Unit of the Federal Institute of Industrial Research, Lagos, Nigeria based on methods described in Bergey's Manual of Systematic Bacteriology [14] and maintained on nutrient agar slants stored at $4^{\circ} \mathrm{C}$.

\subsection{Submerged Fermentation}

Seed inoculum was prepared by growing a loopful of slant culture of B. subtilis SHS-04 in $20 \mathrm{~mL}$ of seed medium containing $0.75 \%(\mathrm{w} / \mathrm{v})$ peptone, $0.5 \%(\mathrm{w} / \mathrm{v}) \mathrm{glu}-$ cose, $0.05 \%(\mathrm{w} / \mathrm{v}) \mathrm{NaCl}$ and $0.01 \%(\mathrm{w} / \mathrm{v}) \mathrm{MgSO}_{4} \cdot 7 \mathrm{H}_{2} \mathrm{O}$ in a $200 \mathrm{~mL}$ conical flask with $\mathrm{pH}$ adjusted to 8.0. The inoculated seed medium was incubated at $37^{\circ} \mathrm{C}$ for $24 \mathrm{~h}$ at $180 \mathrm{rpm}$ in a shaking incubator (Stuart, UK). The $24 \mathrm{~h}$ old seed culture was used as inoculum for the production media. $2.5 \mathrm{~mL}$ of seed inoculum (constituting $5 \% \mathrm{v} / \mathrm{v}$ ) was transferred into $50 \mathrm{~mL}$ of production media which had same composition as the seed medium. At the end of $48 \mathrm{~h}$ incubation period, cultures were harvested by centrifugation at $10,000 \mathrm{rpm}$ for $15 \mathrm{~min}$ at $4^{\circ} \mathrm{C}$. The cell free supernatant was recovered as crude enzyme preparation and used for further studies.

\subsection{Assay of Protease Activity}

Protease activity was determined by a modified procedure based on Fujiwara et al. [15] using 1.0\% casein in $50 \mathrm{mM}$ Glycine-NaOH buffer $(\mathrm{pH} 9.0)$ as substrate. The assay mixture consisted of $2.0 \mathrm{~mL}$ of substrate and 0.5 $\mathrm{mL}$ of enzyme solution in $50 \mathrm{mM}$ Glycine- $\mathrm{NaOH}$ buffer $(\mathrm{pH} 9.0)$. The reaction mixture was incubated at $40^{\circ} \mathrm{C}$ for $30 \mathrm{~min}$ and reaction was terminated by the addition of $2.5 \mathrm{~mL}$ of $10 \%(\mathrm{w} / \mathrm{v})$ trichloroacetic acid. The mixture was allowed to stand for $15 \mathrm{~min}$ and then centrifuged at $10,000 \mathrm{rpm}$ for $10 \mathrm{~min}$ at $4^{\circ} \mathrm{C}$ to remove the resulting precipitate. Protease activity was determined by estimating the amount of tyrosine in the supernatant which was done by measuring the absorbance at $280 \mathrm{~nm}$. One unit of protease activity was defined as the amount of enzyme required to release $1 \mu \mathrm{g}$ of tyrosine per $\mathrm{mL}$ per minute under the mentioned assay conditions.

\subsection{Determination of Growth Kinetics and Protease Production of $B$. subtilis SHS-04}

Growth kinetics over the cultivation period and production of protease were studied by cultivating the bacteria for $12,24,36,48,60,72$ and $84 \mathrm{~h}$ at $\mathrm{pH} 9.0$ and $45^{\circ} \mathrm{C}$ at $200 \mathrm{rpm}$. The growth of the microorganism was determined by measuring the absorbance of culture at $600 \mathrm{~nm}$. The cultures were centrifuged at the end of each cultivation period and the supernatants were used for determination of protease activity which was the measure of protease production.

\subsection{Effect of Temperature on Growth and Protease Production}

Optimal temperature for growth and protease production by $B$. subtilis SHS-04 was determined by investigating growth kinetics and protease production at fixed media concentration and $\mathrm{pH}$ with varying temperatures. Cultures were grown at $20^{\circ} \mathrm{C}, 30^{\circ} \mathrm{C}, 37^{\circ} \mathrm{C}, 40^{\circ} \mathrm{C}, 45^{\circ} \mathrm{C}$, $50^{\circ} \mathrm{C}$, and $60^{\circ} \mathrm{C}$ at $200 \mathrm{rpm}, \mathrm{pH} 9.0$ for $48 \mathrm{~h}$ which was the cultivation period for optimal growth of microorganism and protease production obtained earlier in this study.

\subsection{Effect of pH on Growth and Protease Production}

Cultures of $B$. subtilis SHS-04 were grown at fixed media concentration and temperature, $45^{\circ} \mathrm{C}$ and varying 
$\mathrm{pH}$ of 6.0 to 11.0 at $200 \mathrm{rpm}$ for $48 \mathrm{~h}$ using $50 \mathrm{mM}$ of the following buffer solutions: sodium citrate $(\mathrm{pH}$ 6.0), Tris- $\mathrm{HCl}(\mathrm{pH} 7.0$ to 8.0$)$ and glycine- $\mathrm{NaOH}(\mathrm{pH} 9.0$ to 11.0) for media preparation. Optimal $\mathrm{pH}$ for growth and protease production by $B$. subtilis SHS-04 was determined at the end of the cultivation period by measuring the absorbance of culture at $600 \mathrm{~nm}$ and determining protease activity in the cell free supernatant obtained after centrifugation at $10,000 \mathrm{rpm}$ and $4^{\circ} \mathrm{C}$ for $15 \mathrm{~min}$.

\subsection{Effect of Nitrogen Sources on Growth Kinetics and Protease Production}

Protease production from B. subtilis SHS-04 was investigated using various nitrogen sources which included inexpensive and readily available groundnut meal, locust bean meal and soybean meal. Other nitrogen sources tested were gelatin, beef extract and peptone. Effects of various nitrogen sources $(0.75 \%, \mathrm{w} / \mathrm{v})$ on growth and protease production were studied at $\mathrm{pH} 9.0$ and temperature, $45^{\circ} \mathrm{C}$. Groundnut meal, beef extract, locust bean meal, gelatin, yeast extract and soybean meal were used to substitute peptone in different production media. Cultures were grown for $48 \mathrm{~h}$ at $200 \mathrm{rpm}$; growth and protease production were measured at the end of the cultivation period to determine the best nitrogen sources for optimal enzyme production.

\subsection{Effect of Carbon Sources on Growth Kinetics and Protease Production}

Various carbon sources were investigated for their effects on protease production by $B$. subtilis SHS-04 at $\mathrm{pH}$ 9.0 and temperature, $45^{\circ} \mathrm{C}$. The carbon sources $(0.5 \%$, $\mathrm{w} / \mathrm{v})$ tested are fructose, maltose, lactose, yam flour, sucrose and soluble starch. These were used to replace glucose in different production media. Cultures were grown for $48 \mathrm{~h}$ at $200 \mathrm{rpm}$. Growth and protease production were measured at the end of the cultivation period to determine the best carbon sources for optimal enzyme production.

\subsection{Effect of Temperature on Activity and Stability of Protease}

Effect of temperature on activity of crude enzyme was determined by incubating the reaction mixture at temperatures ranging from $30^{\circ} \mathrm{C}$ to $80^{\circ} \mathrm{C}$ for $30 \mathrm{~min}$ in the presence and absence of $5 \mathrm{mM} \mathrm{CaCl}_{2}$ then the activity of the protease was measured. The thermal stability was determined by incubating the crude protease at temperatures ranging from $50^{\circ} \mathrm{C}$ to $80^{\circ} \mathrm{C}$ in the presence and absence of $5 \mathrm{mM} \mathrm{CaCl}_{2}$ for $30,60,90$ and $120 \mathrm{~min}$, respectively and the residual protease activity was determined according to the standard assay procedure.

\subsection{Effect of pH on Activity and Stability of Protease}

The effect of $\mathrm{pH}$ on activity of protease was determined by assaying for enzyme activity at different $\mathrm{pH}$ values ranging from 4.0 to 12.0 . The $\mathrm{pH}$ was adjusted using $50 \mathrm{mM}$ of the following buffer solutions: sodium acetate $(\mathrm{pH} 4.0$ to 5.0$)$, sodium citrate (6.0), Tris- $\mathrm{HCl}$ (pH 7.0 to 8.0) and glycine- $\mathrm{NaOH}(\mathrm{pH} 9.0$ to 12.0$)$. Reaction mixtures were incubated at $40^{\circ} \mathrm{C}$ for $30 \mathrm{~min}$ and the activity of the protease was measured. To determine the effect of $\mathrm{pH}$ on stability of protease, the protease was incubated in relevant buffers of varying $\mathrm{pH}$ (4.0 to 12.0) without substrate for $60 \mathrm{~min}$ at $40^{\circ} \mathrm{C}$. The residual protease activity was determined as described earlier.

\subsection{Effects of Organic Solvents on Activity and Stability of Protease}

Effects of glycerol, methanol, isopropanol, dimethyl sulfoxide (DMSO), benzene, and acetone on crude protease activity were studied by introducing the selected organic solvent into the reaction mixture at a final concentration of $25 \% \mathrm{v} / \mathrm{v}$ and protease activity was determined according to the standard assay procedure. Organic solvent stability of protease was investigated by pre-incubating $0.75 \mathrm{~mL}$ of crude protease with $0.25 \mathrm{~mL}$ of organic solvent at $40^{\circ} \mathrm{C}$ for $30 \mathrm{~min}$ with shaking. The residual protease activity was determined according to the standard assay procedure and compared with the control. Distilled water was used to replace organic solvent in the control.

\section{RESULTS AND DISCUSSION}

\subsection{Growth Kinetics of $B$. subtilis SHS-04 and Protease Production}

Growth kinetics of B. subtilis SHS-04 and protease production were studied to determine the cultivation period that favours maximum yield of enzyme and evaluate the effect of growth of organism on protease production. Growth of organism was exponential up to $48 \mathrm{~h}$, followed by a stationary phase (Figure 1). Protease production started in the exponential phase corresponding with growth of organism and optimum production of $464.5 \mathrm{U} /$ $\mathrm{mL}$ was evident at 48 hour which was the late exponential phase of B. subtilis SHS-04. This suggests that production of protease by this Bacillus sp. is dependent on cell growth. Incubation time has been reported to play substantial role in enzyme production $[4,16,17]$. There was decline in protease production after $48 \mathrm{~h}$ (Figure 1) which could be due to autolysis of the protease which was consequent upon accumulation of the enzyme in the production media. 


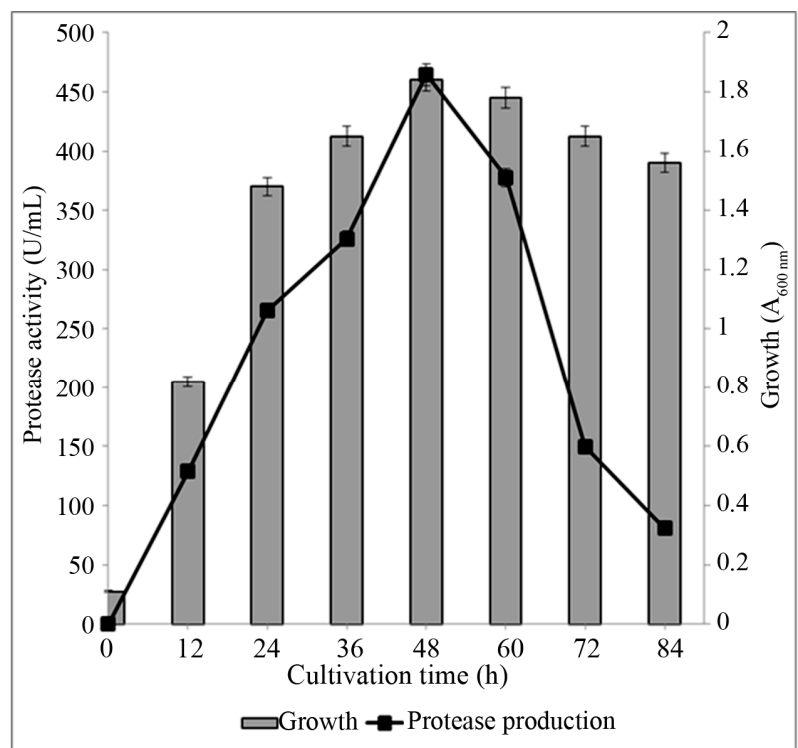

Figure 1. Growth kinetics of B. subtilis SHS-04 and protease production over $84 \mathrm{~h}$ cultivation period. Protease activity $(\mathrm{U} / \mathrm{mL})$ was used to measure protease production. Symbols and bars represent mean values and standard deviations of triplicate determinations.

\subsection{Effects of Temperature on Growth and Production of Protease}

In bioprocesses, specific temperature requirement and its regulation is one of the most critical parameters [18]. B. subtilis SHS-04 exhibited cell growth and protease production at all temperatures studied $\left(20^{\circ} \mathrm{C}\right.$ to $\left.60^{\circ} \mathrm{C}\right)$. Optimum temperature for cell growth was $37^{\circ} \mathrm{C}$ but optimum protease production was recorded at $45^{\circ} \mathrm{C}$ (Figure 2). Sepahy and Jabalameli [19] reported a similar finding on a Bacillus $s p$. with maximum protease production at $45^{\circ} \mathrm{C}$. Gouda [20] reported a lower optimum temperature of $30^{\circ} \mathrm{C}$ for protease production by Bacillus sp. MIG and Nascimento [21] reported a higher optimum temperature of $60^{\circ} \mathrm{C}$ for Bacillus sp. SMIA-2, respectively. Cultivation temperature affects protein synthesis by influencing rate of biochemical reactions within the cell and consequently inducing or repressing enzyme production [22].

\subsection{Effects of pH on Growth and Production of Protease}

B. subtilis SHS-04 grew over the entire $\mathrm{pH} 6.0$ - 11.0 studied with optimum growth recorded at $\mathrm{pH}$ 9.0. Protease production followed same trend as cell growth with optimum enzyme production of $462.6 \mathrm{U} / \mathrm{mL}$ at $\mathrm{pH} 9.0$ (Figure 3). Cell growth and protease production declined after pH 9.0. Bacillus sp. strain APP1 also grew well in $\mathrm{pH}$ range $5.0-12.0$ but demonstrated optimum protease production at $\mathrm{pH} 9.0$ [23]. Similar finding was reported by Joshi et al. [24] on Bacillus cereus which showed

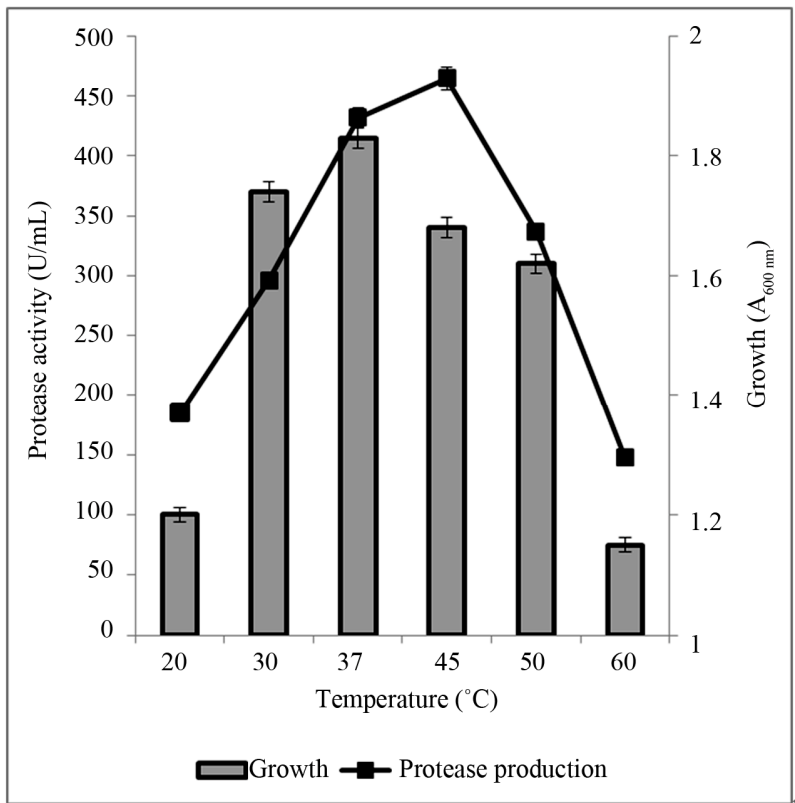

Figure 2. Effects of temperature on growth and protease production over $48 \mathrm{~h}$ cultivation period. Symbols and bars represent mean values and standard deviations of triplicate determinations.

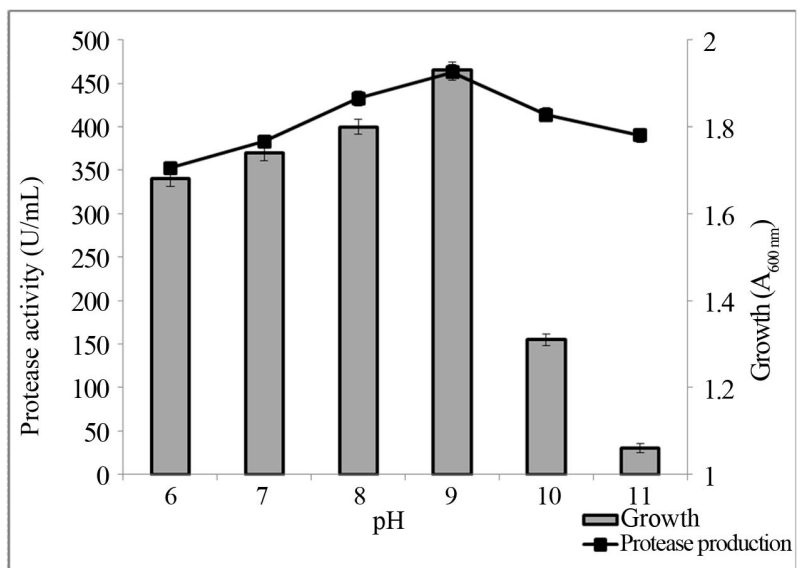

Figure 3. Effects of $\mathrm{pH}$ on growth and protease production over $48 \mathrm{~h}$ cultivation period. Symbols and bars represent mean values and standard deviations of triplicate determinations.

maximum protease production at $\mathrm{pH}$ 9.0. Some have reported optimum protease production at $\mathrm{pH} 7.0$ and 8.0 $[21,25]$. Further studies to optimize protease production from B. subtilis SHS-04 were carried out at $\mathrm{pH} 9.0$. The $\mathrm{pH}$ of culture medium has earlier been reported to have strong influence on metabolic processes within the cell [26].

\subsection{Effects of Nitrogen Sources on Growth and Production of Protease}

All the nitrogen sources studied supported cell growth and protease production from $B$. subtilis SHS-04 at $\mathrm{pH}$ 
9.0 and temperature $45^{\circ} \mathrm{C}$. However, maximum enzyme production of $1616.2 \mathrm{U} / \mathrm{mL}$ was achieved with groundnut meal as nitrogen source (Figure 4). This was 348\% increase in protease production over what was obtained in the basal media which contained peptone as nitrogen source. Groundnut meal served as complex organic nitrogen source and also provided vitamins and minerals [13] which in this study promoted growth and enzyme production in B. subtilis SHS-04. The stimulative role of oil seed cakes on alkaline protease production has been reported in some studies [27]. Beef extract and soybean meal supported $234 \%$ and $145 \%$ increase in protease yield over peptone. These findings show that organic nitrogen sources are effectively utilized for protease production [4]. Joo and Chang [7] reported optimum protease production from Bacillus sp. I-312 in a medium containing wheat flour and soybean meal as the carbon and nitrogen sources. Furthermore, protease production from Bacillus cereus MCM B-326 using media containing deoiled groundnut cakes have been reported but with enzyme yield below $200 \mathrm{U} / \mathrm{mL}$ [28]. The protease production by B. subtilis SHS-04 using groundnut meal as nitrogen source in the present study has greatly enhanced protease production more than other nitrogen sources studied. These results indicate that groundnut meal is an excellent low-cost and readily available substrate for protease production by $B$. subtilis SHS- 04 .

\subsection{Effects of Carbon Sources on Growth and Production of Protease}

B. subtilis SHS-04 grew and produced protease in the presence of various carbon sources tested (Figure 5).

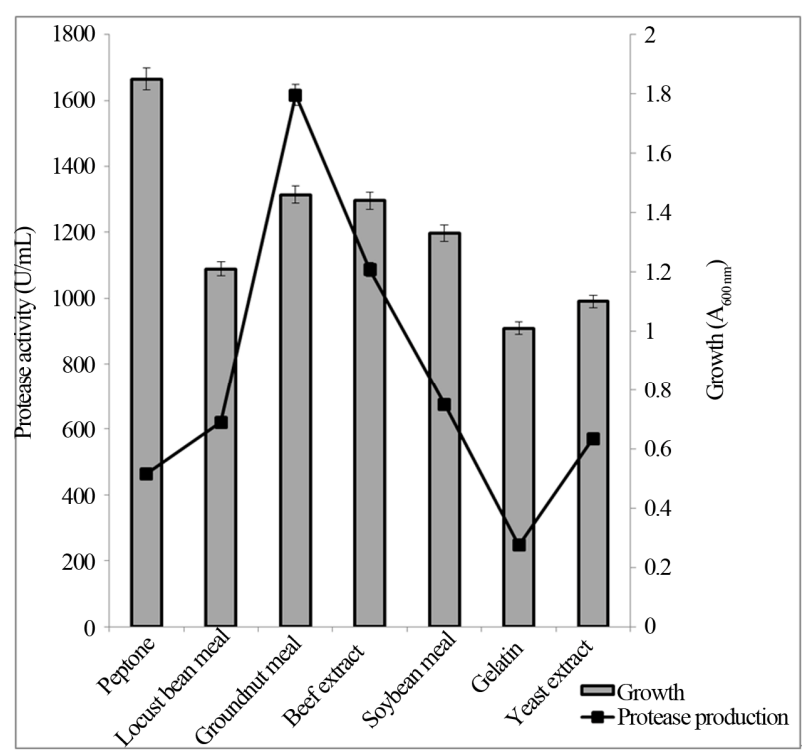

Figure 4. Effects of nitrogen sources on growth and protease production. Symbols and bars represent mean values and standard deviations of triplicate determinations.

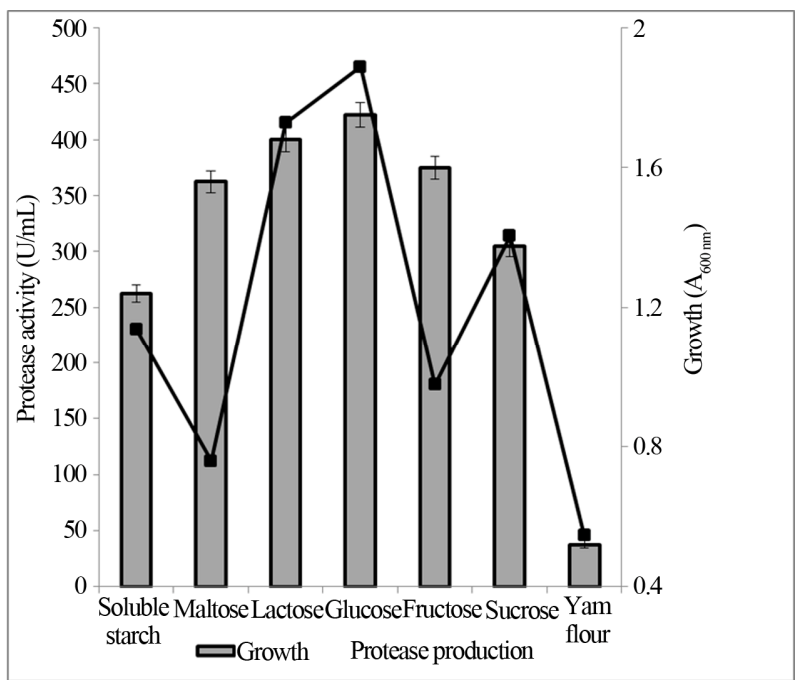

Figure 5. Effects of carbon sources on growth and protease production. Symbols and bars represent mean values and standard deviations of triplicate determinations.

However, only glucose and lactose were most effectively utilized by the organism for protease production with optimum enzyme production of $465.2 \mathrm{U} / \mathrm{mL}$ in the presence of $0.5 \%$ glucose and $415.0 \mathrm{U} / \mathrm{mL}$ with $0.5 \%$ lactose. Protease production was repressed in the presence of fructose, maltose and soluble starch (Figure 5). Our results agree with some earlier reports where production of extracellular protease was enhanced in the presence of glucose as carbon sources [7,29]. However, other previous studies have reported the repression of protease production by glucose $[24,30]$.

\subsection{Thermostability of Crude Protease}

It has been well reported that the stability of alkaline proteases is dependent on calcium ion [31-33]. It is highly remarkable that alkaline protease from $B$. subtilis SHS-04 demonstrated unique stability both in the presence and absence of $\mathrm{Ca}^{2+}$ with optimum temperature of $60^{\circ} \mathrm{C}$ as shown in Figure 6. The protease had relative activity of $80 \%$ at $70^{\circ} \mathrm{C}$ in the absence of $\mathrm{Ca}^{2+}$ and $89 \%$ relative activity in the presence of $\mathrm{Ca}^{2+}$. The enzyme retained $76 \%$ of its original activity at $80^{\circ} \mathrm{C}$ in the presence of $5 \mathrm{mM} \mathrm{Ca}^{2+}$ and exhibited $46 \%$ relative activity in the absence of calcium ion at $80^{\circ} \mathrm{C}$ (Figure 6). Some reports on crude and purified thermo tolerant protease show considerable activity over $40^{\circ} \mathrm{C}$ to $65^{\circ} \mathrm{C}$ but are completely inactivated at $80^{\circ} \mathrm{C}[25,34,35]$. The protease under study showed very high thermostability retaining $99 \%$ of its original activity at $60^{\circ} \mathrm{C}$ after $60 \mathrm{~min}$ of incubation at $\mathrm{pH} 9.0$ in the presence of $5 \mathrm{mM} \mathrm{Ca}^{2+}$ as shown in Figure 7 and $78 \%$ in the absence of $\mathrm{Ca}^{2+}$. The thermostability decreased sharply on increase of temperature to $70^{\circ} \mathrm{C}$ exhibiting $46 \%$ residual activity in the presence of $\mathrm{Ca}^{2+}$ and $35 \%$ residual activity in the absence of this 


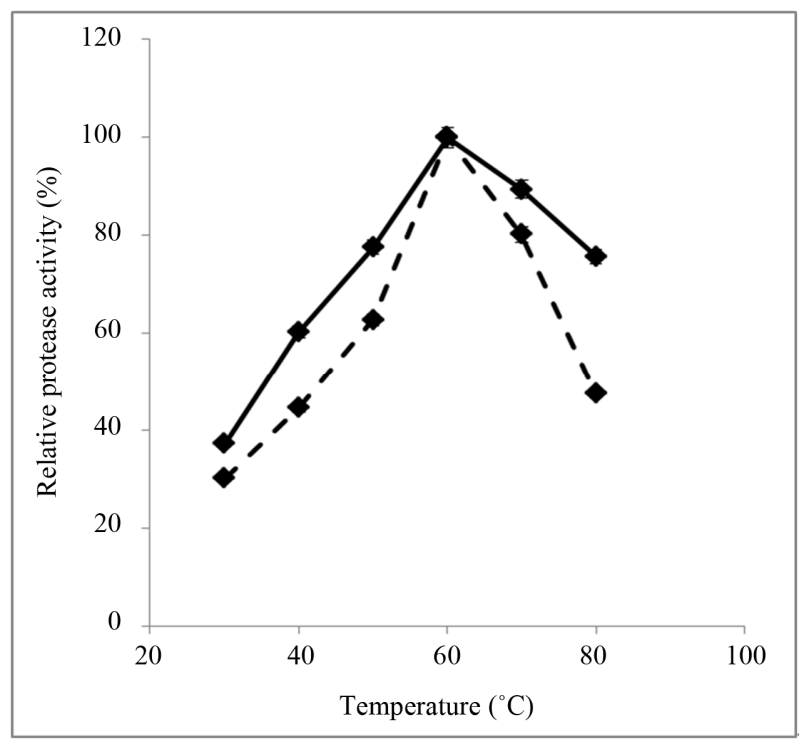

Figure 6. Effect of temperature on activity of protease from Bacillus subtilis SHS-04 in the presence (bold line) and absence of $\mathrm{CaCl}_{2}$ (dashed line).

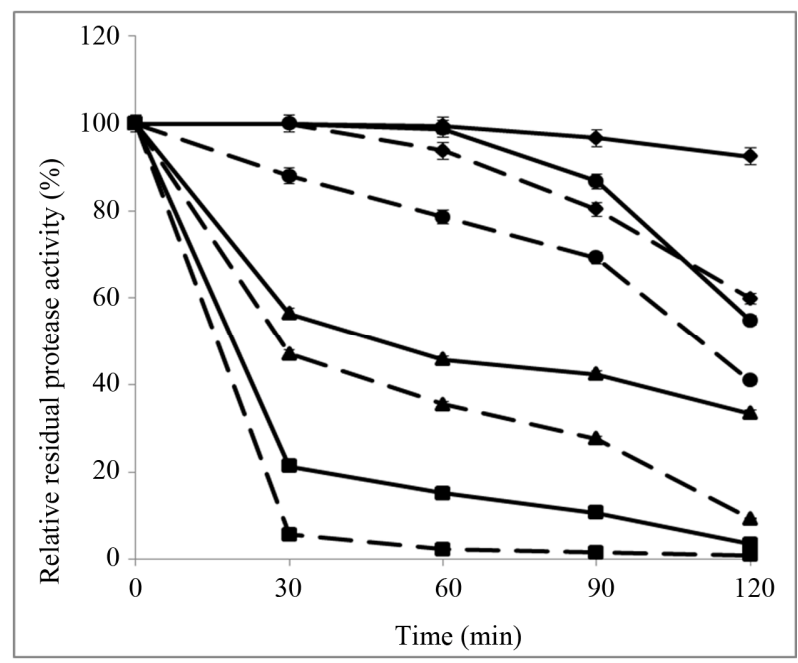

Figure 7. Thermostability of protease in the absence (dashed lines) and presence (bold lines) of $5 \mathrm{mM} \mathrm{CaCl}_{2}$. Stability at $50^{\circ} \mathrm{C}(\bullet), 60^{\circ} \mathrm{C}(\bullet), 70^{\circ} \mathrm{C}(\boldsymbol{\Delta})$ and $80^{\circ} \mathrm{C}(\boldsymbol{\bullet})$ were determined by assaying for activity of enzyme after incubation at specified temperatures for 30, 60, 90 and 120 minutes, respectively.

metal ion at $70^{\circ} \mathrm{C}$ after $60 \mathrm{~min}$ of incubation at $\mathrm{pH} 9.0$ (Figure 7). These results are similar to earlier reports which show that calcium was required for the stability of proteases $[31,36]$. This is further established by Alexander et al. [33] who reported that there are two calciumbinding sites in the crystal structure of subtilisin which play very important role in maintaining the thermostability.

\section{7. pH Stability of Crude Protease}

The optimum $\mathrm{pH}$ for protease activity was 9.0 . The protease activity rapidly declined above $\mathrm{pH} 9.0$ with the enzyme having relative activity of 53\% at $\mathrm{pH} 10.0$ (Figure 8), the activity decreased significantly after $\mathrm{pH} 11.0$ showing only $11 \%$ relative activity at $\mathrm{pH} 12.0$. The enzyme was very stable over a broad range of $\mathrm{pH}$ (7.0 11.0). The important detergent enzymes, subtilisin Carlberg and subtilisin Novo showed maximum activity at $\mathrm{pH}$ values of 8.0 - 10.0 [30].

\subsection{Organic Solvent Stability of Protease}

Microbial proteases have been successfully applied to the synthesis of several small peptides of pharmaceutical and nutritional interests [37]. However, the use of proteases in peptide synthesis is limited by the specificity and the instability of the enzymes in the presence of organic solvents [36]. Protease from B. subtilis SHS-04 had shown remarkable activity and stability in the presence of the organic solvents studied (Figure 9). Protease showed above $80 \%$ relative activity in the presence of acetone, methanol and glycerol when compared with control. The enzyme had relative activity of $78 \%$ and $66 \%$ in the presence of isopropanol and DMSO. The activity of the protease was inhibited by almost $50 \%$ in the presence of benzene (Figure 9). The effect of organic solvents on stability of protease was determined by preincubating the enzyme with selected organic solvent $(25 \% \mathrm{v} / \mathrm{v})$ for $30 \mathrm{~min}$ with shaking. Figure 9 shows that protease from B. subtilis SHS-04 retained above $90 \%$ of its original activity in the presence of DMSO, acetone

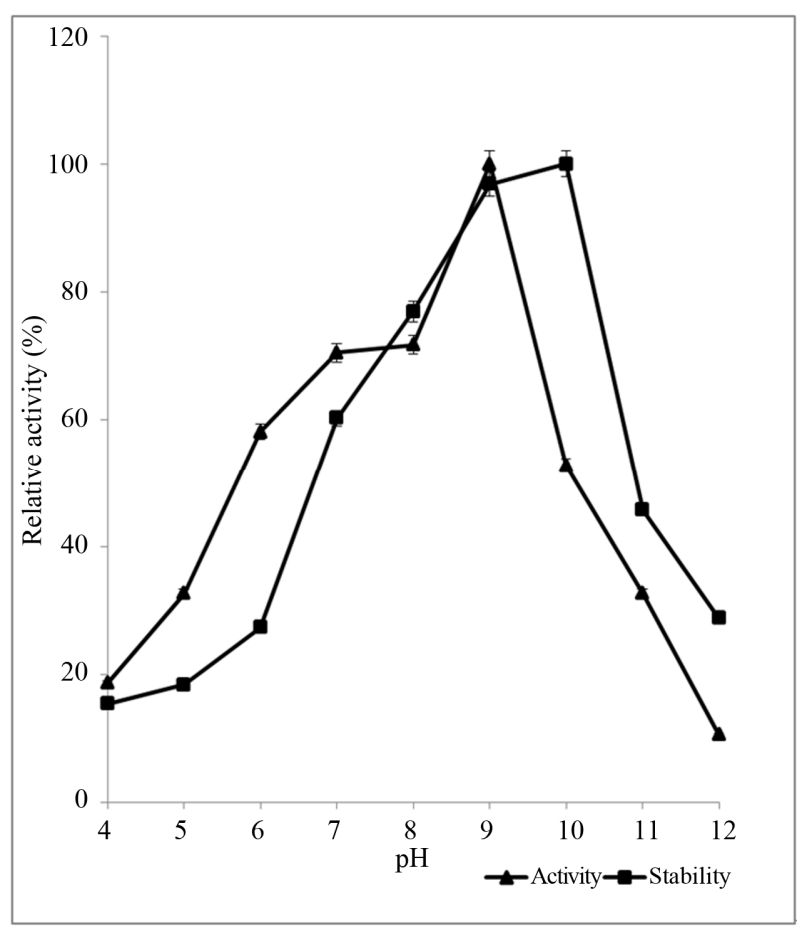

Figure 8. Effect of $\mathrm{pH}$ on activity and stability of protease from Bacillus subtilis SHS-04. 


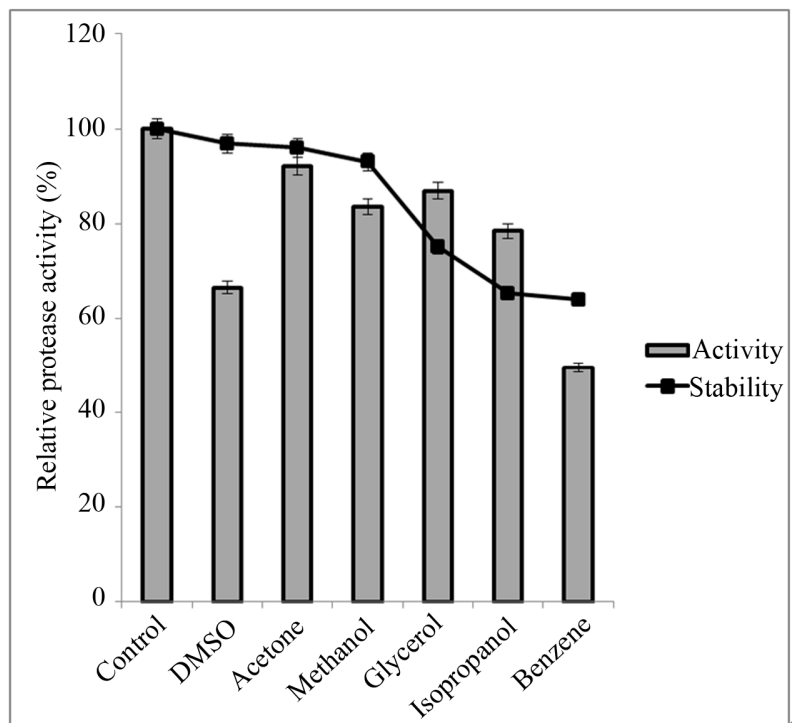

Figure 9. Effect of organic solvents $(25 \% \mathrm{v} / \mathrm{v})$ on activity and stability of protease from B. subtilis SHS-04. Symbols and bars represent mean values and standard deviations of triplicate determinations. Dimethyl sulfoxide is abbreviated DMSO.

and methanol with $75 \%, 65 \%$ and $64 \%$ residual activity in the presence of glycerol, isopropanol and benzene. This property is highly remarkable when compared with the alkaline protease reported by Hadj-Ali et al. [36] from Bacillus licheniformis NH1which exhibited only $12 \%$ residual activity in the presence of isopropanol. Also, a purified protease from Pseudomonas aeruginosa PseA strain was stable in the presence of some organic solvents but unstable in benzene [38]. However, the protease under study from B. subtilis SHS-04 was stable in the presence of isopropanol, benzene, DMSO, acetone, methanol and glycerol.

\section{CONCLUSION}

This study ascertains groundnut meal as the most effective low-cost substrate for protease production from $B$. subtilis SHS-04. The optimized condition for maximum enzyme production $(1616.21 \mathrm{U} / \mathrm{mL})$ using groundnut meal $(0.75 \%)$ was achieved at $48 \mathrm{~h}$ cultivation period, $\mathrm{pH} 9,45^{\circ} \mathrm{C}$ and $200 \mathrm{rpm}$. The enzyme produced was stable over a wide range of $\mathrm{pH}$ and temperature, and in the presence of organic solvents. The use of low-cost growth medium for protease production would significantly reduce the cost of enzyme production.

\section{ACKNOWLEDGEMENTS}

The author is very grateful to the International Foundation for Science (IFS), Sweden for supporting this research through the awarded IFS grant (F/3775-2). Author also acknowledges with thanks the support received from Mr. Olatope and staff of the Biotechnology Unit of Federal Institute of Industrial Research, Lagos in identification of bac- terial isolates.

\section{REFERENCES}

[1] Maurer, K. (2004) Detergent proteases. Current Opinion in Biotechnology, 15, 330-334. http://dx.doi.org/10.1016/j.copbio.2004.06.005

[2] Vellard, M. (2003) The enzyme as drug: Application of enzymes as pharmaceuticals. Current Opinion in Biotechnology, 14, 444-450.

http://dx.doi.org/10.1016/S0958-1669(03)00092-2

[3] Breithaupt, H. (2001) The hunt for living gold. EMBO Reports, 2, 968-971. http://dx.doi.org/10.1093/embo-reports/kve238

[4] Rahman, R.N.Z.A., Geok L.P., Basri M. and Salleh A.B. (2005) Physical factors affecting the production of organic solvent-tolerant protease by Pseudomonas aeruginosa strain K. Bioresource Technology, 96, 429-436. http://dx.doi.org/10.1016/j.biortech.2004.06.012

[5] Joo, H.S., Kumar, C.G., Park, G.C., Kim, K.T., Paik, S.R. and Chang, C.S. (2002) Optimization of the production of an extracellular alkaline protease from Bacillus horikoshi. Process Biochemistry, 38, 155-159.

http://dx.doi.org/10.1016/S0032-9592(02)00061-4

[6] Li, Y., Lin, J., Meng, D., Lu, J., Gu, G. and Mao, Z. (2006) Effect of $\mathrm{pH}$, cultivation time and substrate concentrations on the endoxylanase production by A. awamori $\mathrm{ZH}-26$ under submerged fermentation using central composite rotary design. Food Technology and Biotechnology, 44, 473-477.

[7] Joo, H.-S. and Chang, C.S. (2005) Production of protease from a new alkalophilic Bacillus sp. I-312 grown on soybean meal: Optimization and some properties. Process Biochemistry, 40, 1263-1270. http://dx.doi.org/10.1016/j.procbio.2004.05.010

[8] Haddar, A., Hmidet, N., Ghorbel-Bellaaj, O., FakhfakhZouari, N., Sellami-Kamoun, A. and Nasri, M. (2011) Alkaline proteases produced by Bacillus licheniformis RP1 grown on shrimp wastes: Application in chitin extraction, chicken feather degradation and as a dehairing agent. Biotechnology and Bioprocess Engineering, 16, 669-678. http://dx.doi.org/10.1007/s12257-010-0410-7

[9] Agrebi, R., Hmidet, N., Hajji, M., Ktari, N., Haddar, A., Fakhfakh-zouari, N., et al. (2010) Fibrinolytic serine protease isolation from Bacillus amyloliquefaciens An6 grown on Mirabilis jalapa tuber powders. Applied Biochemistry and Biotechnology, 162, 75-88. http://dx.doi.org/10.1007/s12010-009-8800-z

[10] Bassam, N. El. (2010) Groundnut (Arachis hypogaea (L) Merr.). In: Handbook of Bioenergy Crops: A Complete Reference to Species, Development and Applications, Earthscan Publishers, London, 199-202.

[11] Yaw, A.J., Richard, A., Osei, S., Kofi, A.H., Seth, O. and Adelaide, A. (2008) Chemical composition of groundnut, Arachis hypogaea (L) landraces. African Journal of Biotechnology, 7, 2203-2208.

[12] Ingale, S. and Shrivastava, S.K. (2011) Nutritional study of new variety of groundnut (Arachis hypogaea L.) JL-24 
seeds. African Journal of Food Science, 5, 490-498.

[13] Savage, G.P. and Keenan, J.I. (1994) The composition and nutritive value of groundnut kernels. In: Smart, J., Ed., The Groundnut Crop: Scientific Basis for Improvement, Chapman and Hall, London, 173-213. http://dx.doi.org/10.1007/978-94-011-0733-4_6

[14] Vos, P., et al. (2010) The Firmicutes. In: Vos, P., Garrity, G., Jones, D., Krieg, N.R., Ludwig, W., Rainey, F.A., Schleifer, K. and Whitman, W.B., Eds., Bergey's Manual of Systematic Bacteriology, 2nd Edition, Volume 3, Springer, New York, 4-325.

[15] Fujiwara, N., Masui, A. and Imanaka, T. (1993) Purification and properties of highly thermostable alkaline protease from an alkalophilic and thermophilic Bacillus $s p$. Journal of Biotechnology, 30, 245-256. http://dx.doi.org/10.1016/0168-1656(93)90117-6

[16] Olajuyigbe, F.M. and Ajele, J.O. (2005) Production dynamics of extracellular protease from Bacillus species. African Journal of Biotechnology, 4, 776-779.

[17] Olajuyigbe, F.M. and Ajele, J.O. (2011) Thermostable alkaline protease from Bacillus licheniformis LBBL-11 isolated from traditionally fermented African locust bean (Parkia biglobosa). Journal of Food Biochemistry, 35, 1-10. http://dx.doi.org/10.1111/j.1745-4514.2010.00362.x

[18] Singh, S.K., Tripathi, V.R., Khare, S.K. and Garg, S.K. (2011) Comparative one-factor-at-a-time, response surface (statistical) and bench-scale bioreactor level optimization of thermoalkaline protease production from a psychrotrophic Pseudomonas putida SKG-1 isolate. Microbial Cell Factories, 10, 114. http://dx.doi.org/10.1186/1475-2859-10-114

[19] Sepahy, A.A. and Jabalameli, L. (2011) Effect of culture conditions on the production of an extracellular protease by Bacillus sp. isolated from soil sample of Lavizan Jungle Park. Enzyme Research, 2011, Article ID: 219628. http://dx.doi.org/10.4061/2011/219628

[20] Gouda, M.K. (2006) Optimization and purification of alkaline proteases produced by marine Bacillus sp. MIG newly isolated from Eastern Harbour of Alexandria. Polish Journal of Microbiology, 55, 119-126.

[21] Nascimento, W.C.A. and Martins, M.L.L. (2004) Production and properties of an extracellular protease from thermophilic Bacillus sp. Brazilian Journal of Microbiology, 35, 1-2. http://dx.doi.org/10.1590/S1517-83822004000100015

[22] Bakermans, C. and Nealson, K.H. (2004) Relationship of critical temperature to macromolecular synthesis and growth yield in Psychrobacter cryopegella. Journal of Bacteriology, 186, 2340-2345. http://dx.doi.org/10.1128/JB.186.8.2340-2345.2004

[23] Chu, W.-H. (2007) Optimization of extracellular alkaline protease production from species of Bacillus. Journal of Industrial Microbiology and Biotechnology, 34, 241-245. http://dx.doi.org/10.1007/s10295-006-0192-2

[24] Joshi, R.H., Dodia, M.S. and Singh, S.P. (2008) Production and optimization of a commercially viable alkaline protease from a haloalkaliphilic bacterium. Biotechnology and Bioprocess Engineering, 13, 552-559. http://dx.doi.org/10.1007/s12257-007-0211-9

[25] Abusham, R.A., Zaliha, R.N., Salleh, A.B. and Basri, M. (2009) Optimization of physical factors affecting the production of thermo-stable organic solvent-tolerant protease from a newly isolated halotolerant $B$. subtilis strain Rand. Microbial Cell Factories, 8, 20.

http://dx.doi.org/10.1186/1475-2859-8-20

[26] Fang, H.H.P. and Liu, H. (2002) Effect of pH on hydrogen production from glucose by mixed culture. Bioresource Technology, 82, 87-93. http://dx.doi.org/10.1016/S0960-8524(01)00110-9

[27] Ellaiah, P., Srinivasulu, B. and Adinarayana, K. (2002) A review on microbial alkaline proteases. Journal of Scientific and Industrial Research, 61, 690-704.

[28] Zambare, V.P., Nilegaonkar, S.S. and Kanekar, P.P. (2004) Production of an alkaline protease by Bacillus cereus MCM B-326 and its application as a dehairing agent. World Journal of Microbiology and Biotechnology, 23, 1569-1574. http://dx.doi.org/10.1007/s11274-007-9402-y

[29] Mehrotra, S., Pandey, P.K., Gaur, R. and Darmwal, N.S. (1999) The production of alkaline protease by a Bacillus species isolate. Bioresource Technology, 67, 201-203. http://dx.doi.org/10.1016/S0960-8524(98)00107-2

[30] Gupta, R., Beg, Q.K. and Lorenz, P. (2002) Bacterial alkaline proteases: Molecular approaches and industrial applications. Applied Microbiology and Biotechnology, 59, 15-32. http://dx.doi.org/10.1007/s00253-002-0975-y

[31] Wan, M.-Y., Wang, H-Y., Zhang, Y.-Z. and Feng, H. (2009) Substrate specificity and thermostability of the dehairing alkaline protease from Bacillus pumilus. Applied Biochemistry and Biotechnology, 159, 394-403. http://dx.doi.org/10.1007/s12010-008-8497-4

[32] Ghorbel, B., Sellami-kamoun, A. and Nasri, M. (2003) Stability studies of protease from Bacillus cereus BG1. Enzyme and Microbial Technology, 32, 513-518. http://dx.doi.org/10.1016/S0141-0229(03)00004-8

[33] Alexander, P.A., Ruan, B., Strausberg, S.L. and Bryan, P. N. (2001) Cation-dependent stability of subtilisin. Biochemistry, 40, 10640-10644. http://dx.doi.org/10.1021/bi010798e

[34] Nilegaonkar, S.S., Zambare, V.P., Kanekar, P.P., Dhakephalkar, P.K. and Sarnaik, S.S. (2007) Production and partial characterization of dehairing protease from Bacillus cereus MCMB-326. Bioresource Technology, 98, 1238-1245. http://dx.doi.org/10.1016/j.biortech.2006.05.003

[35] Rai, S.K., Roy, J.K. and Mukherjee, A.K. (2010) Characterisation of a detergent-stable alkaline protease from a novel thermophilic strain Paenibacillus tezpurensis $s p$. nov. AS-S24-II. Applied Microbiology and Biotechnology, 85, 1437-1450. http://dx.doi.org/10.1007/s00253-009-2145-y

[36] Hadj-Ali, N.E., Agrebi, R., Ghorbel-Frikha, B., SellamiKamoun, A., Kanoun, S. and Nasri, M. (2007) Biochemical and molecular characterization of a detergent stable alkaline serine-protease from a newly isolated $\mathrm{Ba}$ cillus licheniformis NH1. Enzyme and Microbial Tech- 
nology, 40, 515-523.

http://dx.doi.org/10.1016/j.enzmictec.2006.05.007

[37] Kumar, D. and Bhalla, T.C. (2005) Microbial proteases in peptide synthesis: Approaches and applications. Applied Microbiology and Biotechnology, 68, 726-736. http://dx.doi.org/10.1007/s00253-005-0094-7
[38] Gupta, A., Roy, I., Khare, S.K. and Gupta, M.N. (2005) Purification and characterization of a solvent stable protease from Pseudomonas aeruginosa PseA. Journal of Chromatography A, 1069, 155-161.

http://dx.doi.org/10.1016/j.chroma.2005.01.080 